\title{
QUALITY OF APPLE MAIDENS AS INFLUENCED BY THE FREQUENCY OF APPLICATION OF DIFFERENT FERTILIZERS IN THE ORGANIC NURSERY - PRELIMINARY RESULTS
}

\author{
Zygmunt S. Grzyb, Wojciech Piotrowski, Paweł Bielicki \\ and Lidia Sas Paszt
}

\author{
Research Institute of Horticulture, Department of Pomology \\ Pomologiczna 18, 96-100 Skierniewice, POLAND \\ e-mail: zygmunt.grzyb@inhort.pl
}

(Received June 29, 2012/Accepted December 14, 2012)

\section{A B S T R A C T}

A study was conducted in an organic nursery, in 2010 and 2011, on the growth of scab-resistant maiden apple trees of the cultivars Topaz and Ariwa grafted on M.26 rootstock. The young trees were grown at a spacing of $25 \mathrm{~cm} \times 1.0 \mathrm{~m}$ on a podzolic soil. On the basis of the differences in the thickness and height of the maidens, and the number of lateral shoots and their length, as well as the number of branched trees, the effects of various fertilizers were studied depending on the number of treatments applied to the plants, which were treated either once or twice with such products as granulated manure, Micosat, Humus UP, Humus Active + Aktywit PM, BF Amin, BF Quality, Tytanit and Vinassa. The control plants were not fertilized at all, or fertilized with NPK. The fertilizers were applied the first time to the soil and plants in the nursery in mid-May and the second time in early June. The results showed that using them in a double treatment did not result in improved plant growth in every case. Two applications of humic preparations, the so-called vermiculites (Humus UP, Humus Active + Aktywit PM with the addition of beneficial bacteria), BF Quality, and to some extent also BF Amin gave better results in terms of the quality of maiden trees than a single application of these products, whereas in the case of preparations such as Tytanit and Vinassa, treating plants with them for the second time did not result in a significant increase in the intensity of plant growth in relation to the plants treated only once during the early period of growth.

Key words: bioproducts, organic nursery, maidens of apple trees, application frequency. 


\section{INTRODUCTION}

Fertilization of plants should be effective and economical (Wang et al., 2009) - effective enough to make the plants grow and develop vigorously, and economical so as not to introduce to the soil products which plants are not able to use, and which will only poison the soil and groundwater (Ekologiczne.., 2005). This is what usually happens with nitrogen (Prasad and Power, 1991; Tyburski and Żukowska-Biemans, 2007). Determination of fertilization needs for different plant species and of specific doses for use in their nutrition will bring benefits both to the plants and the manufacturer of such products. When using organic products (plant extracts and products resulting from the activities of the Californian earthworm, the so-called vermiculites), it is not always possible to determine the dose precisely (Wertheim and Easterbrook's, 1994; Kuwada et al., 2006; Sas Paszt et al., 2011). Neither is it known whether they should be applied to the soil or the leaves only once at the beginning of the growing season, nor whether this treatment should be repeated later to increase their effect (Grzyb et al., 2012a). Detailed information about influence of different fertilizers an the growth and quality of apple fruit tree maidens are presented in separate paper submitted to print in Acta Horticulturae (Grzyb et al., 2012b). The aim of this study is to provide, as far as possible, a precise answer to a question thus posed and to show the interested parties what benefits can be obtained in that respect.

\section{MATERIAL AND METHODS}

The study was conducted in 20102011 in an experimental nursery located in Mokra Lewa near Skierniewice, on a podzolic soil. The experiment was set up in a randomised block design with four replications, each consisting of 10 plants. The treatments were applied in the first year (2010) of running the nursery, on M.26 apple rootstocks and in the second year, after grafting, on maiden trees of two apple cultivars (Topaz and Ariwa).

The following treatments were applied:

1 Control.

2 Chemical NPK fertilization: at a dose of $17.64 \mathrm{~g} \cdot \mathrm{m}^{-2} \mathrm{NH}_{4} \mathrm{NO}_{3}$, $6.52 \mathrm{~g} \cdot \mathrm{m}^{-2}$ triple super phosphate, and $16.0 \mathrm{~g} \cdot \mathrm{m}^{-2} \mathrm{~K}_{2} \mathrm{SO}_{4}$, equivalent to $60 \mathrm{~kg} \cdot \mathrm{ha}^{-1} \mathrm{~N}, 30 \mathrm{~kg} \cdot \mathrm{ha}^{-1} \mathrm{P}$, and $80 \mathrm{~kg} \cdot \mathrm{ha}^{-1} \mathrm{~K}$.

3 Fertigo (Ferm-O-Feed, the Netherlands) - granulated bovine manure containing $55 \% \mathrm{C}, 1 \% \mathrm{~N}$, $0.3 \% \mathrm{P}$ and $1 \% \mathrm{~K}$; besides these, also microelements and soil micro-organisms. The product was applied at a dose of $150 \mathrm{~g} \cdot \mathrm{m}^{-2}$ (1500 $\left.\mathrm{kg} \cdot \mathrm{ha}^{-1}\right)$, equivalent to $45 \mathrm{~kg} \cdot \mathrm{ha}^{-1} \mathrm{~N}, 13 \mathrm{~kg} \cdot \mathrm{ha}^{-1} \mathrm{P}$ and $17 \mathrm{~kg} \cdot \mathrm{ha}^{-1} \mathrm{~K}$.

4 Micosat (CCS Aosta Srl, Italy) microbial inoculum consisting of mycorrhizal fungi (Glomus mosseae and $G$. intraradices), and plant growth promoting bacteria (Pseudomonas fluorescence and Bacillus subtilis strains). The product contains $40 \% \mathrm{C}, 0.15 \% \mathrm{~N}, 431$ $\mathrm{mg} \cdot \mathrm{kg}^{-1} \mathrm{P}$ and $9558 \mathrm{mg} \cdot \mathrm{kg}^{-1} \mathrm{~K}$; the 
granular formulation Micosat F12 WP was applied at planting to the soil at a dose of $10 \mathrm{~g} \cdot \mathrm{m}^{-2}$ $\left(100 \mathrm{~kg} \cdot \mathrm{ha}^{-1}\right)$, and a second application was carried out in midJune in liquid form (Micosat F MS 200) at a dose of $1 \mathrm{~g} \cdot \mathrm{m}^{-2}$ $\left(10 \mathrm{~kg} \cdot \mathrm{ha}^{-1}\right)$

5 Humus UP (Ekodarpol, Poland) an extract from vermicomposts containing $0.65 \% \mathrm{C}, 0.03 \% \mathrm{~N}$, $30.8 \mathrm{mg} \cdot \mathrm{kg}^{-1} \mathrm{P}$ and $4535 \mathrm{mg} \cdot \mathrm{kg}^{-1}$

$\mathrm{K}$. The product was applied to the soil as a $2 \%$ solution $\left(2 \mathrm{ml} \cdot \mathrm{m}^{-2}\right)$ $\left(201 \cdot \mathrm{ha}^{-1}\right)$.

6 Humus Active + Aktywit PM (Ekodarpol, Poland) - an extract from vermicomposts based on a product derived from molasses. Humus Active is a soil improver with active humus and population of beneficial microorganisms containing $0.78 \% \mathrm{C}, 0.03 \% \mathrm{~N}$, $1050 \mathrm{mg} \cdot \mathrm{kg}^{-1} \mathrm{P}$ and $4119 \mathrm{mg} \cdot \mathrm{kg}^{-1} \mathrm{~K}$. Aktywit PM is a soil improver containing $20.5 \% \mathrm{C}, 0.92 \% \mathrm{~N}$, $81.2 \mathrm{mg} \cdot \mathrm{kg}^{-1} \mathrm{P}$ and $42990 \mathrm{mg} \cdot \mathrm{kg}^{-1} \mathrm{~K}$. (Humus Active was applied to the soil as a $2 \%$ solution $\left(2 \mathrm{ml} \cdot \mathrm{m}^{-2}\right)$ $\left(201 \cdot \mathrm{ha}^{-1}\right)$ and Aktywit PM was applied to the soil as a $1 \%$ solution $-1 \mathrm{ml} \cdot \mathrm{m}^{-2}\left(10 \mathrm{l} \cdot \mathrm{ha}^{-1}\right)$.

7 BioFeed Amin (Agrobio Products B.V., the Netherlands) - an extract reinforced with amino acids - an extract of vegetal amino acids containing $1.12 \% \mathrm{C}, 0.14 \% \mathrm{~N}$, $347 \mathrm{mg} \cdot \mathrm{kg}^{-1} \mathrm{P}$. The product was applied to the soil as a $0.5 \%$ solution $\left(0.5 \mathrm{ml} \cdot \mathrm{m}^{-2}\right)\left(5 \mathrm{l} \cdot \mathrm{ha}^{-1}\right)$.

8 BioFeed Quality (Agrobio Products B.V., the Netherlands) - an extract from several seaweed spe- cies reinforced with humic and fulvic acids containing $0.6 \% \mathrm{C}$, $0.07 \% \mathrm{~N}, 32.6 \mathrm{mg} \cdot \mathrm{kg}^{-1} \mathrm{P}$. (applied to the soil as a $0.5 \%$ solution $\left(0.5 \mathrm{ml} \cdot \mathrm{m}^{-2}\right)\left(5 \mathrm{l} \cdot \mathrm{ha}^{-1}\right)$.

9 Tytanit (Intermag, Poland) - titanium (Ti) applied to the leaves as a $0.05 \%$ solution $\left(0.05 \mathrm{ml} \cdot \mathrm{m}^{-2}\right)$ $\left(0.51 \cdot \mathrm{ha}^{-1}\right)$.

10 Vinassa (Józefów Sp. z o.o., Poland) - molasses residue from yeast production containing $12.0 \% \mathrm{C}$, $1.86 \% \quad \mathrm{~N}, \quad 949 \mathrm{mg} \cdot \mathrm{kg}^{-1} \mathrm{P}$, $17615 \mathrm{mg} \cdot \mathrm{kg}^{-1} \mathrm{~K}$. The product was applied to the soil as a $0.5 \%$ solution $\left(0.5 \mathrm{ml} \cdot \mathrm{m}^{-2}\right)\left(51 \cdot \mathrm{ha}^{-1}\right)$.

The plants treated with Micosat, BF Quality, BF Amin, Tytanit and Vinassa were planted in the soil which had been fertilized with half the dose of granulated bovine manure $\left(75 \mathrm{~g} \cdot \mathrm{m}^{-2}\right)$.

All the fertilizers except NPK and bovine manure (Fertigo) were applied - one year earlier on the rootstocks, then in maidens nursery twice - in middle on May, and middle of June. After the application of the preparations the soil around the plants was each time thoroughly mixed by hand using hoes.

In the autumn, before digging up the trees from the nursery, measurements of their trunk diameter at a height of $30 \mathrm{~cm}$ above ground and of their height were taken; the number of branched trees (expressed as percent of number trees with lateral shoots in each combination) and the length and number of lateral shoots were recorded. Only the lateral shoots longer than $5 \mathrm{~cm}$ were included in the measurements. 
Data for the plants with different fertilizers were analyzed statistically using two-factor analysis of variance. Comparison of single and double application for each combination was performed with suitably defined contrasts at the significance level of $p=0.05$.

\section{RESULTS}

The effects of single and double applications of the biopreparations on the growth and development of maiden apple trees of the cultivars Topaz (A) and Ariwa(B) are shown in Table 1.

Maiden trees of the apple 'Topaz' (Tab. 1A) treated once and twice with the various bioproducts had a similar diameter of the trunk. The influence of the number of treatments on the height of the maidens was not significant. An exception were the maidens treated with $\mathrm{BF}$ Quality, where its repeated use was more effective than a single application.

All the maidens of this apple cultivar, regardless of the number of treatments, had a similar capacity for branching. However, applying the preparations Humus UP and $\mathrm{BF}$ Amin twice had a greater effect on the number of lateral shoots than a single application of these products.

The total length of annual shoots for single and double treatments of the plants with the biopreparations was similar. An exception were the combinations where Micosat, Humus Active + Aktywit PM, and BF Quality were used. When applied to the same plants for the second time, these preparations increased the total length of lateral shoots by nearly fifty percent, which was not observed in the other treatment combinations in the nursery.

Maidens of the apple 'Ariwa' (Tab. 1B), regardless of whether they had been treated once or twice with the biopreparations, had a similar trunk diameter. An exception was the combination with Tytanit, where using it once was more effective than using it twice.

The fact that the preparations were applied once or twice had no major effect on the height of 'Ariwa' maiden apple trees. An exception were the trees treated with Micosat. After this preparation had been applied twice, the trees were found to be about fifty percent taller than after a single application of this product.

The number of treatments had no significant effect on the process of branching in this cultivar's maiden trees.

The increase in the number of lateral shoots was significantly stimulated with such preparations as $\mathrm{BF}$ Quality and BF Amin. This was more evident following a single rather than double treatment.

When applied twice, such products as Humus UP and BF Quality significantly increased the growth in length of lateral shoots, whereas in the case of Humus Active + Aktywit PM and Tytanit the single application was more effective than the double treatment. 
Table 1. Parametric features of maiden apple trees 'Topaz' (A) and 'Ariwa' treated in an organic nursery (1) - once, and (2) - twice with different fertilizers (Mokra Lewa, 2011)

A - 'Topaz' cv.

\begin{tabular}{|c|c|c|c|c|c|c|c|c|c|c|}
\hline \multirow[t]{2}{*}{ Treatment } & \multicolumn{2}{|c|}{$\begin{array}{l}\text { Trunk diam- } \\
\text { eter } \\
{[\mathrm{mm}]}\end{array}$} & \multicolumn{2}{|c|}{$\begin{array}{l}\text { Tree height } \\
{[\mathrm{cm}]}\end{array}$} & \multicolumn{2}{|c|}{$\begin{array}{c}\text { Number of } \\
\text { branched trees } \\
(\mathrm{x}) \\
{[\%]}\end{array}$} & \multicolumn{2}{|c|}{$\begin{array}{l}\text { Number of } \\
\text { lateral } \\
\text { shoots }\end{array}$} & \multicolumn{2}{|c|}{$\begin{array}{l}\text { Total length of } \\
\text { lateral shoots } \\
{[\mathrm{cm}]}\end{array}$} \\
\hline & 1 & 2 & 1 & 2 & 1 & 2 & 1 & 2 & 1 & 2 \\
\hline Control $^{(\mathrm{y})}$ & 12.4 & 12.5 & 111 & 107 & 43.2 & 51.3 & 1.1 & 1.5 & 14.0 & 15.7 \\
\hline NPK & 14.2 & 14.3 & 126 & 124 & 60.0 & 67.1 & 1.7 & 2.1 & 27.9 & 24.9 \\
\hline $\begin{array}{l}\text { Fertigo } \\
\text { manure }\end{array}$ & 14.1 & 14.1 & 114 & 117 & 72.5 & 78.8 & 1.6 & 2.3 & 22.4 & 23.9 \\
\hline Micosat & 14.3 & 13.8 & 122 & 120 & 67.5 & 72.9 & 2.1 & 2.5 & 25.1 & $48.7^{*}$ \\
\hline Humus UP & 13.2 & 13.1 & 117 & 119 & 60.4 & 81.7 & 1.7 & $2.7 *$ & 34.1 & 25.2 \\
\hline $\begin{array}{l}\text { Humus } \\
\text { Active + } \\
\text { Aktywit PM }\end{array}$ & 14.3 & 13.9 & 123 & 124 & 78.7 & 77.1 & 2.6 & 2.4 & 35.9 & $47.0^{*}$ \\
\hline BF Quality & 14.2 & 14.8 & 122 & $131 *$ & 75.0 & 88.8 & 2.3 & 3.0 & 24.7 & $57.0^{*}$ \\
\hline BF Amin & 13.6 & 14.0 & 122 & 123 & 76.7 & 81.7 & 1.6 & $2.7 *$ & 35.5 & 40.4 \\
\hline Tytanit & 13.4 & 14.3 & 124 & 124 & 72.5 & 74.6 & 1.4 & 2.1 & 24.4 & 30.3 \\
\hline Vinassa & 14.0 & 14.5 & 127 & 126 & 77.5 & 75.8 & 1.8 & 2.6 & 30.5 & 34.0 \\
\hline
\end{tabular}

B - 'Ariwa' cv.

\begin{tabular}{|c|c|c|c|c|c|c|c|c|c|c|}
\hline \multirow[t]{2}{*}{ Treatment } & \multicolumn{2}{|c|}{$\begin{array}{l}\text { Trunk di- } \\
\text { ameter } \\
{[\mathrm{mm}]}\end{array}$} & \multicolumn{2}{|c|}{$\begin{array}{l}\text { Tree height } \\
{[\mathrm{cm}]}\end{array}$} & \multicolumn{2}{|c|}{$\begin{array}{c}\text { Number of } \\
\text { branched trees } \\
(\mathrm{x}) \\
{[\%]}\end{array}$} & \multicolumn{2}{|c|}{$\begin{array}{l}\text { Number } \\
\text { of lateral } \\
\text { shoots }^{\#}\end{array}$} & \multicolumn{2}{|c|}{$\begin{array}{c}\text { Total length of } \\
\text { lateral shoots } \\
{[\mathrm{cm}]}\end{array}$} \\
\hline & 1 & 2 & 1 & 2 & 1 & 2 & 1 & 2 & 1 & 2 \\
\hline Control $^{(y)}$ & 13.5 & 12.4 & 148 & 146 & 69.6 & 70.8 & 3.8 & 3.9 & 124.6 & 128.9 \\
\hline NPK & 14.1 & 14.0 & 160 & 159 & 82.5 & 75.0 & 4.5 & 4.2 & 159.0 & 153.8 \\
\hline $\begin{array}{l}\text { Fertigo } \\
\text { manure }\end{array}$ & 13.0 & 13.8 & 157 & 155 & 89.6 & 80.0 & 4.7 & 4.8 & 178.4 & 170.6 \\
\hline Micosat & 12.8 & 13.6 & 152 & $168^{*}$ & 87.5 & 85.0 & 3.9 & 3.9 & 152.2 & 161.7 \\
\hline Humus UP & 13.4 & 12.9 & 161 & 156 & 83.9 & 89.2 & 3.3 & 3.8 & 122.9 & $146.4^{*}$ \\
\hline $\begin{array}{l}\text { Humus } \\
\text { Active }+ \\
\text { Aktywit PM }\end{array}$ & 13.7 & 13.7 & 158 & 158 & 91.7 & 76.3 & 4.5 & 4.0 & $139.5^{*}$ & 80.9 \\
\hline BF Quality & 13.0 & 13.8 & 159 & 160 & 97.5 & 97.5 & $4.9 *$ & 3.5 & 124.2 & $175.0^{*}$ \\
\hline BF Amin & 13.6 & 14.5 & 163 & 159 & 95.0 & 97.5 & $4.3^{*}$ & 3.3 & 156.0 & 169.0 \\
\hline Tytanit & $13.6^{*}$ & 11.9 & 155 & 147 & 95.0 & 79.6 & 3.8 & 2.9 & $118.7 *$ & 91.1 \\
\hline Vinassa & 12.6 & 13.2 & 154 & 157 & 95.0 & 89.6 & 4.3 & 4.4 & 130.3 & $186.6^{*}$ \\
\hline
\end{tabular}

Note: \# - shoots longer than $5 \mathrm{~cm}$

* - significant differences between single (1) and double (2) treatments

(y) - no fertilization

(x) - expressed as percent of number trees with lateral shoots in each combination 


\section{DISCUSSION}

The most effective in their action on plant growth are nitrogen compounds (Wójcik, 2005; 2009). They stimulate mainly the apical growth of plants, not always giving them the opportunity to develop lateral shoots. An example of this can be the treatments employed in nurseries whose production is based on conventional methods, where, in order to increase the capacity of maiden trees for branching, use is made of compounds that inhibit the rapid growth of the leader (Basak, 2009). Effective inhibition of apical bud growth initiates the formation of lateral branches (Wertheim and Estabbrooks, 1994). To improve the quality of trees produced in organic nurseries, attempts are made to use various bioproducts (Klamkowski et al., 1999; Nardi et al., 2002; Kuwada et al., 2006; Khan et al., 2009). As yet, their influence on the development of young trees in the nursery is not understood well enough. Many data indicate that when they are used at the right time and in the right doses, they can significantly improve the quality of the nursery stock produced, which is not inferior in this respect to the quality of trees produced in nurseries run by conventional methods (Grzyb et al., 2012a). Among the bioproducts that are already known and recommended for production in organic nurseries, and new products available for testing, selection should be made of those that meet our expectations (Skupień and Oszmianski, 2007; Basak, 2008; Sas Paszt et al., 2011).
What needs to be optimized are the doses and times of their application. The important question is not only when but also in what quantity and how many times they should be used to obtain the desired results. Our findings show that a repetition of the same treatment does not necessarily lead in every case to an increased biological effect of a given product. Tytanit is a good example of this. On the other hand, such products as Micosat, BF Quality, BF Amin, Vinassa and Humus Active in conjunction with beneficial microorganisms (Aktywit PM) used more than once give a significant improvement in the quality of the material being produced, either in the form of taller and well-branched trees or a greater yield (number of trees) from one hectare (Kuwada et al., 2006). If, at the same time, a given product improves the ability of buds (scions) to 'take', or reduces their susceptibility to freezing, then the effect of this product will be fully satisfactory. Accurate determination of the number of treatments necessary to obtain the desired effects, which has been noted by other authors (Wertheim and Estabbrooks, 1994), will not only reduce unnecessary labour costs but also save money on the purchase of organic fertilizers, whose repeated use to improve the quality of the plants under production is not effective enough or even unnecessary.

\section{CONCLUSIONS}

1. A single application of the preparation Tytanit in the organic 
nursery seems to be a sufficient treatment for improving the quality of maiden apple trees.

2. The biological activity of such preparations as Micosat, BF Amin, BF Quality and Vinassa used in the organic nursery of apple trees increases with the number of treatments performed. In terms of the quality of maiden trees, using these preparations twice is more effective than a single application.

3. Cultivars of apple trees in the nursery respond differently to the same number of treatments with given biopreparations. In some of them, sufficiently good results are obtained with a single treatment, while to achieve a similar effect in others, the same treatment must be performed twice.

4. Regardless of the number of treatments, vermiculites (humic preparations) seem to be less effective in stimulating the growth of maiden apple trees than the extracts from marine plants $(\mathrm{BF}$ Quality) and terrestrial plants (BF Amin), or the preparation Vinassa.

5. Mineral fertilization, the way it is commonly used in conventional nurseries, results in apple maidens whose quality is, if not poorer, at least comparable with those that are fertilized with organic products. The advantage of the latter is that not only do they improve the process of branching in maiden trees, but also stimulate the growth intensity of the lateral shoots growing out of them.
Acknowledgment: The work has been supported by a grant from the EU Regional Development Fund through the Polish Innovation Economy Operational Programme, contract No. UDA-POIG01.03.01-10109/08-00.

\section{REFERENCES}

Basak A. 2008. Effect of preharvest treatment with seaweed products Klepak SL and Goemar 86BM on the apple quality of cvs 'Gala', 'Golden Delicious', 'Jonagold'. INT. J. FRUIT SCI. 8(1-2): 1-14.

Basak A. 2009. Regulatory wzrostu w matecznikach, szkółkach i młodych sadach. Plantpress Warsaw, pp. 3-95.

Ekologiczne metody produkcji owoców 2005. In: E. Żurawicz ed., Centrum Doradztwa Rolniczego w Brwinowie Oddział w Radomiu, pp. 1-126.

Grzyb Z.S., Bielicki P., Piotrowski W., Sas Paszt L., Malusa E. 2012a. Effect of some organic fertilizers and amendments on the quality of maidens trees of two apple cultivars. Proc. $15^{\text {th }}$ Intern. Konfer. on Organic Fruit Growing. 20 ${ }^{\text {th }}-22^{\text {th }}$ February 2012; (Univ. oh Hohenheim, Germany), pp. 410-414.

Grzyb Z.S., Piotrowski W., Bielicki P., Sas Paszt L. and Malusà E. 2012b. Effect of Organic Fertilizers and Soil Conditioners on the Quality of Apple Maiden Trees. ACTA HORT. (in press).

Khan W., Rayirath U.P., Subramanian S., Jithesh M.N., Rayorath P., Hodges D.M., Critchley A.T,. Craigie J.S., Norrie J., Prithiviraj B. 2009 Seaweed extracts as Bio stimulants of plant growth and development. J. PLANT GROWTH REGUL. 28: 386-399. 
Klamkowski K., Wójcik P., Treder W. 1999. Biomass production and uptake of mineral nutrients by apple tress as influenced by titanium fertilization. J. FRUIT ORNAM. PLANT RES. 7(4) 169-179.

Kuwada K., Wamocho L.S., Utamura M., Matsushita I., Ishii T. 2006. Effect of red and green algal extract on hyphen growth of arbuscular mycorrhizal development and growth of papaya and passion fruit. ARGON. J. 98: 1340-1344.

Nardi S., Pizzeghello D., Muscolo A., Vianello A. 2002. Physiological effects of humic substances on higher plants. SOIL BIOL. BIOCHEM. 34: 1527-1536.

Prasad R., Power J.F. 1991. Crop residue management - literature review. ADV. SOIL SCI. 15: 205-251.

Sas Paszt L., Sumorek B., Malusa E., Głuszek S., Derkowska E. 2011. The influence of bioproducts on root growth and mycorrhizal occurrence in the rhizosphere of strawberry plants 'Elsanta'. J. FRUIT ORNAM. PLANT RES.19(1): 13-34.

Skupień K., Oszmianski J. 2007. Influence o titanium treatment on antioxi- dants and antioxidant activity of strawberries. ACTA SCI. POL., TECHNOLOGIA ALIMENTARIA 6(4): 83-94.

Tyburski J., Żukowska-Biemans S. 2007. Wprowadzenie do rolnictwa ekologicznego. Wyd. SGGW, Warszawa, pp. 1-245.

Wang B., Lai T., Huang Q., Yang X., Shen Q. 2009. Effect of $\mathrm{N}$ fertilizers on root growth and endogenous hormones in strawberry. PODOSPHAERA 19: 86-95.

Wertheim S.J., Estabbrooks E.N. 1994. Effect of repeated sprays of 6benzyloadenine on the formation of sylleptic shoots in apple in fruit nursery. SCI. HORT. 60: 31-39.

Wójcik P. 2005. Nawożenie pozakorzeniowe $w$ uprawie roślin sadowniczych. Modernizacja sadownictwa w dostosowaniu do wymogów Unii Europejskiej. X Ogólno. Spot. Sadow. w Grójcu. Grójec, 19-20 January, pp. 85-92.

Wójcik P. 2009. Nawozy i nawożenie drzew owocowych. Hortpress, Warszawa., pp. 1-254. 


\title{
JAKOŚĆ OKULANTÓW JABŁONI W ZALEŻNOŚCI OD CZECTOTLIWOŚCI STOSOWANIA NAWOZÓW GLEBOWYCH I DOLISTNYCH W SZKÓŁCE EKOLOGICZNEJ - WYNIKI WSTĘPNE
}

\author{
Zygmunt S. Grzyb, Wojciech Piotrowski, Paweł Bielicki \\ i Lidia Sas Paszt
}

\author{
S T R E S Z C Z E N I E
}

W latach 2010 i 2011 w szkółce ekologicznej badano wzrost okulantów jabłoni odpornych na parcha odmian Topaz i Ariwa szczepionych na podkładce M.26. Drzewka rosły na glebie bielicowej w rozstawie $25 \mathrm{~cm}$ x $1.0 \mathrm{~m}$. Efekt działania preparatów stosowanych na rośliny jedno- lub dwukrotnie, takich jak: Micosat, Humus UP, Humus Active + Aktywit PM, BF Amin, BF Quality, Tytani i Vinassa oceniano na podstawie różnicy grubości i wysokości okulantów oraz liczby pędów bocznych i ich długości, a także liczby rozgałęzionych okulantów. Kontrolę stanowiły rośliny niczym nienawożone i nawożone NPK. Pierwszy raz nawozy stosowano na glebę i rośliny w połowie maja, a drugi raz na początku czerwca. Uzyskane wyniki pokazały, że nie w każdym przypadku powtórne stosowanie preparatów poprawia warunki wzrostu roślin. Dwukrotne stosowanie preparatów humusowych vermiculitów $(\mathrm{Hu}-$ mus UP, Humus Active + Aktywit PM z dodatkiem pozytywnych mikroorganizmów), BF Quality, a częściowo także BF Amin dawało lepsze wyniki jakości okulantów niż przy jednokrotnym ich stosowaniu. Natomiast w przypadku preparatów, takich jak Tytanit i Vinassa powtórne traktowanie nimi roślin już nie powodowało istotnego zwiększenia intensywności ich wzrostu w stosunku do traktowanych jednokrotnie we wczesnym okresie ich wegetacji.

Słowa kluczowe: okulanty jabłoni, aplikacja bioproduktów, szkółka ekologiczna, krotność stosowania 